\title{
Klauzula porządku publicznego a uznawanie zagranicznych orzeczeń, których przedmiotem jest uznanie wyroku lub stwierdzenie jego wykonalności
}

\begin{abstract}
The paper is devoted to the admissibility of recognition and enforcement of a judgment of a foreign court, the subject matter of which is recognition or declaration of enforcement of a judgment from yet another state (judgment on judgment). The issue is discussed in particular with reference to the public policy exception which constitutes a ground for refusal of recognition or enforcement of foreign judgments, both under Polish domestic law (the Code of civil procedure) and European law (Brussels I bis Regulation). It remains controversial whether the judgments on judgments should be recognized, thus benefiting from the so called "parallel entitlement". The article takes a comparative approach, examining solutions adopted by various legal systems and analysing arguments for and against recognition of such decisions. The author takes the position that they should not be recognized (and that their enforceability should not be declared) in Poland, both under the Code of civil procedure (as with respect to judgments originating from non-EU states), as well as under EU legislation, in particular Brussels I bis Regulation. It is advocated that the concept of a "parallel entitlement" should be rejected.
\end{abstract}

Keywords: recognition and enforcement of foreign judgments, parallel entitlement, public policy exception, confirmation judgments

a) Dr hab., prof. ALK, Akademia Leona Koźmińskiego w Warszawie. 


\section{Problem dopuszezalności uznania [stwierdzenia wykonalności] orzeczeń zatwierdzających}

Tematem niniejszego opracowania jest zagadnienie dopuszczalności uznania (stwierdzenia wykonalności) orzeczeń zagranicznego sądu, których przedmiotem jest uznanie lub stwierdzenie wykonalności wyroku pochodzącego z innego państwa ${ }^{1}$, w szczególności w zetknięciu z kontrola zagranicznych orzeczeń pod kątem zgodności z porządkiem publicznym fori. W doktrynie używa się w tym kontekście niekiedy określenia „równoległe uprawnienie" takich orzeczeń (parallel entitlement) ${ }^{2}$. Powstaje zasadnicza wątpliwość, czy mają one w ogóle tzw. zdatność uznaniową. Nie zawieraja bowiem merytorycznego rozstrzygnięcia sporu, lecz wypowiadają się jedynie w przedmiocie przesłanek uznania lub stwierdzenia wykonalności wyroku wydanego już przez sąd innego państwa. Stwierdzają one bądź, że wyrok sądu innego państwa nadaje się do uznania bądź nadaja mu exequatur (stwierdzaja jego wykonalność). Warto zwrócić uwagę, że może tu chodzić zarówno o przypadki, w których sąd wydaje orzeczenie na wniosek wierzyciela (jak np. zgodnie z art. 1151 $\S 1$ k.p.c. ${ }^{3} \mathrm{w}$ odniesieniu do stwierdzenia wykonalności), jak i o sytuacje, w których uznanie lub stwierdzenie wykonalności następuje ex lege (jak

${ }^{1} \mathrm{Na}$ temat analogicznego zagadnienia uznawania i wykonywania orzeczeń sądów powszechnych zatwierdzających wyroki sądów arbitrażowych (lub nadających im exequatur) zob.: M. Zachariasiewicz, w: Diagnoza arbitrażu. Funkcjonowanie prawa o arbitrażu i kierunku postulowanych zmian. Red. B. Gessel-Kalinowska vel Kalisz. Wrocław 2014, s. 457 i nast.; Ł. Błaszczak: Wyrok sqdu polubownego w postępowaniu cywilnym. Warszawa 2010, s. 438; T. Várady, J.J. Barceló, A.T. von Mehren: International Commercial Arbitration. St. Paul 1999, s. 606; M.L. Roth: Recognition by Circumvention: Enforcing Foreign Arbitral Award as Judgment under the Parallel Entitlement Approach. "Cornell Law Review" 2007, vol. 92, s. 573 i nast.; L. Silber man, M. Scherer: Forum Shopping and Post-Award Judgments. In: Forum Shopping in the International Commercial Arbitration Context. Ed. F. Ferrari. Münich 2013, s. 313 i nast.; M. Scherer: Effects of Foreign Judgments Relating to International Arbitral Awards: Is the 'Judgment Route' the Wrong Road? "Journal of International Dispute Settlement" 2013, vol. 4, no. 3, s. 587 i nast.; T. Einhorn: The Recognition and Enforcement of Foreign Judgments on International Commercial Arbitral Awards. "Yearbook Private International Law" 2010, vol. 12, s. 43 i nast.

${ }^{2}$ Zob. w kontekście równoległego uprawnienia orzeczeń uznających lub stwierdzajacych wykonalność wyroków sądów arbitrażowych: T. Várady, J.J. Barceló, A.T. von Mehren: International..., s. 606; M.L. Roth: Recognition..., s. 580; L. Silberman, M. Scherer: Forum..., s. 330.

${ }^{3}$ Ustawa z dnia 17 listopada 1964 r. - Kodeks postępowania cywilnego. Dz.U. nr 43, poz. $296 \mathrm{ze} \mathrm{zm}$. 
na tle rozporządzenia Bruksela I bis ${ }^{4}$ ), ale na skutek inicjatywy zainteresowanej strony, sąd wydaje orzeczenie potwierdzające, że uznanie lub stwierdzenie wykonalności rzeczywiście nastąpiło, ponieważ nie zachodzą ku temu negatywne przesłanki (np. art. 45-46 rozporządzenia Bruksela I bis). Dla uproszczenia, wszystkie orzeczenia, których przedmiotem jest uznanie lub stwierdzenie wykonalności wyroku pochodzącego z innego państwa nazywać będziemy „orzeczeniami zatwierdzającymi” ( $\mathrm{z}$ ang. confirmation judgments / recognition judgments / judgments on judgments).

Chodzi tu zatem o następujace sytuacje. Wierzyciel, uzyskawszy korzystne rozstrzygnięcie sądu w państwie X (nazwijmy je „państwem pierwotnego wyroku”), kieruje swe kroki do państwa A w celu potwierdzenia, że wyrok podlega uznaniu lub stwierdzeniu wykonalności w tym kraju („państwo pośredniego uznania lub wykonania”). Następnie składa on wniosek do sądu w państwie B (,państwo docelowego uznania lub wykonania”), żądając uznania lub stwierdzenia wykonalności orzeczenia sądu państwa A, którego przedmiotem było uznanie lub stwierdzenie wykonalności wyroku sądu państwa X. Jeden z wariantów, który szczególnie mamy tu na względzie zakłada, że o ile państwo X jest państwem spoza UE, to państwa A i B są członkami UE. Problem powstaje jednak również w innych konfiguracjach, w tym w całości unijnych (X, A i B są państwami unijnymi), jak i takich, w których chodziłoby o uznanie (stwierdzenie wykonalności), orzeczenia zatwierdzającego wydanego przez sąd państwa trzeciego (X i A są państwami spoza UE, B jest państwem unijnym).

W niniejszym opracowaniu przyglądam się zagadnieniu uznawania (stwierdzenia wykonalności) orzeczeń zatwierdzających na tle kilku obcych porządków prawnych. Wskazuję na argumenty przemawiajace za i przeciwko dopuszczalności uznawania i stwierdzenia wykonalności takich orzeczeń. Na wstępie należy też zaznaczyć, że niniejsze opracowa-

\footnotetext{
${ }^{4}$ Rozporządzenie Parlamentu Europejskiego i Rady (UE) nr 1215/2012 z 12.12.2012 r. $\mathrm{w}$ sprawie jurysdykcji i uznawania orzeczeń sądowych oraz ich wykonywania w sprawach cywilnych i handlowych. Dz.Urz. UE L 351 z 20.12.2012 r., s. 1 [dalej: rozporządzenie Bruksela I bis].

${ }^{5}$ Polskie prawo procesowe, podobnie jak wielu innych państw nie zna sensu stricto tego typu rodzaju orzeczenia. Są one natomiast znane w państwach anglosaskich. Zob. M. Scherer: Les effets des jugements étrangers relatifs aux sentences arbitrales. "Travaux Du Comité Français De Droit International Privé” 2012-2014, Paris 2015, s. 105. Pojęcia „orzeczenia zatwierdzające” używam zatem w tym miejscu w znaczeniu funkcjonalnym, dla określenia wszystkich rozstrzygnięć sądowych, z których wynika, że orzeczenie obcego sądu nadaje się w danym państwie do uznania lub wykonania, bez względu na to czy mają one charakter deklaratoryjny (bo uznanie lub stwierdzenie wykonalności następuje ex lege) czy konstytutywny (bo uznanie lub stwierdzenie wykonalności następuje z mocy rozstrzygnięcia sądu delibacyjnego).
} 
nie koncentruje się na relacji pomiędzy orzeczeniami zatwierdzającymi i klauzula porządku publicznego jako podstawą odmowy uznania lub stwierdzenia wykonalności orzeczenia.

\section{System uznawania i wykonywania zagranicznych orzeczeń sądowych}

Tradycyjnie uznanie oraz wykonanie orzeczenia wydanego przez są innego państwa wymagało przeprowadzenia specjalnego postępowania, zmierzającego do ustalenia czy spełnione sa pozytywne przesłanki uznania lub wykonania (zwłaszcza formalne) oraz czy nie zachodzą negatywne podstawy odmowy uznania lub wykonania (w tym sprzeczność z porząkiem publicznym). Postępowanie tego typu określa się w Polsce z reguły mianem delibacyjnego ${ }^{6}$. W odniesieniu do stwierdzenia wykonalności (orzeczeń, które podlegają wykonaniu) w literaturze światowej używano najczęściej określenia exequatur ${ }^{7}$. Obecnie, uznawanie i stwierdzanie wykonalności zagranicznych orzeczeń odbywa się najczęściej w oparciu o przepisy prawa unijnego. Przepisy te stosuje się bowiem $\mathrm{w}$ odniesieniu do orzeczeń pochodzących z państw członkowskich UE, a to z takimi maja najczęściej do czynienia polskie sądy. Wprawdzie znajduja one zastosowanie pod warunkiem, że chodzi o orzeczenia objęte ich przedmiotowym zakresem zastosowania, ale współcześnie sieć tych regulacji jest na tyle gęsta, że obejmuje większość spraw o charakterze cywilnym

${ }^{6}$ M.P. Wójcik, w: Komentarz aktualizowany do ustawy z dnia 17 listopada 1964 r. Kodeks postępowania cywilnego. Red. A. Jakubecki. LEX el. 2016, kom. do art. 1146, pkt 1; P. Rylski, w: Kodeks postępowania cywilnego. Komentarz. Tom 5: Artykuty 1096-1217. Red. H. Dolecki, T. Wiśniewski. Warszawa 2013, kom. do art. 1146, pkt 1; M. Tomaszewski: Glosa do postanowienia SN z dnia 6 listopada 2009 r., I CSK 159/09. „Orzecznictwo Sąów Powszechnych” 2010, nr 10, poz. 97, s. 690; A. Proksa: Glosa do postanowienia SN z dnia 16 października 1987 r., I CR 230/87. „Państwo i Prawo" 1990, z. 3, s. 106; K. Pia secki: Glosa do postanowienia SN z dnia 29 października 1997 r., III CZP 50/97. „Orzecznictwo Sądów Powszechnych” 1998, nr 7-8, poz. 141.

${ }^{7}$ Zob. np.: G. Cuniberti, I. Rueda: Abolition of Exequatur. "Rabels Zeitschrift für ausländisches und internationales Privatrecht” 2011, H. 2, s. 287; G. Cuniberti: Abolition de l'exequatur et présomption de protection des droits fondamentaux. "Revue Critique de Droit International Privé" 2014, no. 2, s. 303 i nast.; L. Timmer: Abolition of Exequatur Under the Brussels I Regulation: Ill Conceived and Premature? "Journal of Private International Law" 2013, vol. 9, nr 1; P. Beaumont, E. Johnston: Can Exequatur Be Abolished in Brussels I Whilst Retaining a Public Policy Defence?, "Journal of Private International Law" 2010, vol. 6, s. 254. 
i handlowym ${ }^{8}$. Podstawowe znaczenie ma tu oczywiście rozporządzenie Bruksela I bis i to ono będzie zasadniczym punktem odniesienia dla rozważań tu prowadzonych.

W Unii Europejskiej, w ramach rozwijania współpracy sądowej w sprawach cywilnych (zob. art. 81 TFUE) i postępujacej europeizacji międzynarodowego postępowania cywilnego ${ }^{9}$, od lat toczy się proces ułatwiania uznawania i wykonywania orzeczeń pochodzacych z innych państw członkowskich. Odbywa się to przez stopniową redukcję istniejących przeszkód, w tym upraszczanie procedur sądowych wymaganych dla rozciągnięcia skutków orzeczeń z innych państw na terytorium innego państwa członkowskiego. W konwencji brukselskiej z 1968 r. ${ }^{10}$ i rozporządzeniu Bruksela I z 2000 r. dla stwierdzenia wykonalności orzeczenia wymagane było przeprowadzenie specjalnego postępowania delibacyjnego (uzyskanie exequatur). Rozciągnięcie skutków orzeczenia

${ }^{8}$ Poza wspomnianym już rozporządzeniem Bruksela I bis chodzi o: rozporządzenie Rady (WE) nr 2201/2003 z dnia 27 listopada 2003 r. o jurysdykcji oraz uznawaniu i wykonywaniu orzeczeń w sprawach małżeńskich oraz w sprawach dotyczących odpowiedzialności rodzicielskiej, uchylające rozporządzenie (WE) nr 1347/2000; rozporządzenie Rady (WE) nr 4/2009 z dnia 18 grudnia 2008 r. w sprawie jurysdykcji, prawa właściwego, uznawania i wykonywania orzeczeń oraz współpracy w zakresie zobowiązań alimentacyjnych. Dz.Urz. UE L 7 z 10.01.2009, s. 1 [dalej: rozporządzenie alimentacyjne]; rozporządzenie Parlamentu Europejskiego I Rady (UE) nr 650/2012 z dnia 4 lipca 2012 r. w sprawie jurysdykcji, prawa właściwego, uznawania i wykonywania orzeczeń, przyjmowania i wykonywania dokumentów urzędowych dotyczących dziedziczenia oraz w sprawie ustanowienia europejskiego poświadczenia spadkowego. Dz.Urz. UE L 201 z 27.07.2012, s. 107 [dalej: rozporządzenie spadkowe] oraz nieobowiąujące w Polsce: rozporządzenie Rady (UE) 2016/1103 z dnia 24 czerwca 2016 r. wdrażające wzmocniona współpracę w dziedzinie jurysdykcji, prawa właściwego oraz uznawania i wykonywania orzeczeń w sprawach dotyczących małżeńskich ustrojów majątkowych. Dz.Urz. UE L 183 z 8.07.2016, s. 1 [dalej: rozporządzenie dotyczące małżeńskich ustrojów majątkowych] oraz rozporządzenie Rady (UE) 2016/1104 z dnia 24 czerwca 2016 r. wdrażające wzmocnioną współpracę w dziedzinie jurysdykcji, prawa właściwego oraz uznawania i wykonywania orzeczeń w sprawach dotyczących skutków majątkowych zarejestrowanych związków partnerskich. Dz.Urz. UE L 183 z 8.07.2016, s. 30 [dalej: rozporządzenie dotyczące skutków majątkowych związków partnerskich].

${ }^{9}$ Zob. np. K. Weitz: Konwencja z Lugano - wykonalność zagranicznych orzeczeń przed sqdami polskimi. Warszawa 2002, s. 27 i nast.; K. Pia secki: Kodeks postępowania cywilnego. Tom 4: Przepisy z zakresu międzynarodowego postępowania cywilnego. Warszawa 2013, s. 1.

${ }^{10}$ Konwencja o jurysdykcji i wykonywaniu orzeczeń sądowych w sprawach cywilnych i handlowych, podpisana w Brukseli dnia 27 września 1968 r., wersja skonsolidowana opubl. w Dz.Urz. UE C 27 z 26.01.1998, s. 1. Na temat historii powstawania, zmian i zasad rządzących uznawaniem i stwierdzeniem wykonalności orzeczeń na tle konwencji brukselskiej zob. np. obszerne opracowanie: R. Reuland: The Recognition of Judgments in the European Community: The Twenty-Fifth Anniversary of the Brussels Convention. „Michigan Journal of International Law” 1993, vol. 14, s. 559. 
z innego państwa członkowskiego UE (uznanie orzeczenia) następowało natomiast ex lege (automatycznie) bez potrzeby przeprowadzenia jakiegokolwiek postępowania (tzw. model uznania de plano ${ }^{11}$ ). W nowym rozporządzeniu Bruksela I bis przyjętym w 2012 r. - choć przy sprzeciwie części doktryny ${ }^{12}$ — zrezygnowano ${ }^{13}$ jednak z wymogu uzyskania exequatur. W obecnym zatem stanie prawnym nie tylko uznanie ale również stwierdzenie wykonalności orzeczeń z innych państw członkowskich UE następuje automatycznie (ex lege) bez potrzeby przeprowadzania jakiegokolwiek szczególnego postępowania w państwie wykonania orzeczenia (art. 39 rozporządzenia Bruksela I bis). Wierzyciel może zatem kierować orzeczenie pochodzące $\mathrm{z}$ innego państwa członkowskiego bezpośrednio do egzekucji zgodnie z przepisami państwa, w którym ma ona nastąpić.

W przypadku orzeczeń sąów spoza państw członkowskich UE oraz EFTA $^{14}$ (lub niemieszczących się w przedmiotowym zakresie żadnych z rozporządzeń unijnych) zastosowanie znajdują przepisy Kodeksu postępowania cywilnego (art. $1145-1153$ k.p.c.) ${ }^{15}$. Na skutek reformy postępowania cywilnego z 2008 r. ${ }^{16}$, w dużej mierze są one wzorowane na mo-

${ }^{11}$ Zob. P. Grzegorczyk: Stosowanie rozporzadzenia Rady (WE) nr 44/2001 w sprawach dotyczacych uznawania i wykonywania orzeczeń sqdów obcych na tle polskiej praktyki sadowej. „Europejski Przegląd Sądowy” 2016, nr 10, s. 19; K. Weitz: Konwencja..., s. 36 i nast.

12 Tak np. L. Timmer: Abolition of Exequatur..., s. 147; G. Cuniberti: The Recognition of Foreign Judgments Lacking Reasons in Europe: Access to Justice, Foreign Court Avoidance and Efficiency. "International \& Comparative Law Quarterly" 2008, vol. 57, s. 50; G. Cuniberti, I. Rueda: Abolition..., s. 302 i nast.; H. Schack: The Misguided Abolition of Exequatur Proceedings in the European Union. In: "Aurea Praxis Aurea Theoria”. Księga pamiatkowa ku czci profesora Tadeusza Erecińskiego. Tom 1. Red. K. Weitz, J. Gudowski. Warszawa 2011, s. 1358.

${ }^{13}$ Komisja Europejska zapowiedziała działania zmierzające do likwidacji procedury exequatur już w Komunikacie z 1997 r. (COM(1997) 609, final), deklarujacc następnie zamiar kontynuowania tego procesu w 2009 r. w Programie sztokholmskim Otwarta i bezpieczna Europa dla dobra i ochrony obywateli (Dz.Urz. UE C 115 z 4.05.2010, s. 1). Zob. także B. Hess, T. Pfeiffer, P. Schlosser: Report on the Application of Regulation Brussels I in the Member States, 2007 („Heidelberg Report”), s. 241.

${ }^{14} \mathrm{~W}$ odniesieniu do orzeczeń pochodzących z państw EFTA zastosowanie znajduje Konwencja o jurysdykcji i uznawaniu oraz wykonywaniu orzeczeń sądowych w sprawach cywilnych i handlowych, podpisana w Lugano w dniu 30 października 2007 r. Dz.Urz. UE L 147 z 10.06.2009, s. 5.

${ }^{15} \mathrm{Na}$ temat art. 1145-1153 k.p.c. zob. szerzej m.in.: T. Ereciński, w: Kodeks postępowania cywilnego. Komentarz. Tom 6: Międzynarodowe postępowanie cywilne. Sad polubowny (arbitrażowy). Red. T. Ereciński. Warszawa 2017, kom. do art. 1146-1153; M.P. Wójcik, w: Komentarz... Red. A. Jakubecki, kom. do art. 1146-1153; P. Rylski, w: Komentarz... Red. H. Dolecki, T. Wiśniewski, kom. do art. 1146-1153.

${ }^{16}$ Ustawa z dnia 5 grudnia 2008 r. o zmianie ustawy - Kodeks postępowania cywilnego oraz niektórych innych ustaw. Dz.U. 2008, nr 234, poz. 1571 (ustawa weszła w życie 1 lipca 2009 r.). 
delu znanym z rozporządzenia Bruksela I. Uznanie orzeczeń następuje zatem z mocy prawa (art. 1145 k.p.c.), natomiast stwierdzenie wykonalności orzeczeń nadających się do wykonania w drodze egzekucji następuje przez nadanie orzeczeniu sądu państwa obcego klauzuli wykonalności w postępowaniu wszczynanym na wniosek wierzyciela (art. 1151 $\S 1$ k.p.c.).

\section{Klauzula porządku publicznego jako przesłanka odmowy uznania lub stwierdzenia wykonalności zagranicznych orzeczeń}

Klauzula porządku publicznego stanowi jedna z przesłanek odmowy uznania i stwierdzenia wykonalności zagranicznego orzeczenia ${ }^{17}$. Taka odmowa może nastąpić jeżeli uznanie lub wykonanie prowadziłoby do skutków sprzecznych z podstawowymi zasadami porządku prawnego państwa, w którym wierzyciel o to występuje (lub korzysta ze skutków orzeczenia podlegającego uznaniu lub stwierdzeniu wykonalności ex lege).

Klauzula zachowuje swą rolę zarówno na tle przepisów kodeksu postępowania cywilnego (względem orzeczeń pochodzących spoza UE), jak i na tle unijnych przepisów dotyczących uznawania i wykonywania orzeczeń, w szczególności na tle rozporządzenia Bruksela I bis (względem orzeczeń z państw członkowskich UE).

Uznawanie i wykonywanie orzeczeń pochodzących spoza Unii Europejskiej podlega przepisom Kodeksu postępowania cywilnego. Zgodnie z art. $1146 \S 1$ pkt 7 k.p.c., podstawą dla odmowy uznania lub stwierdze-

${ }^{17}$ Szerzej na temat klauzuli porządku publicznego jako przesłanki odmowy uznania lub wykonania zagranicznego orzeczenia w literaturze polskiej zob. np. M. Zachariasiewicz: Klauzula porzadku publicznego jako instrument ochrony materialnoprawnych interesów i wartości fori. Warszawa 2018, s. 78 i nast.; Ł. Goździaszek, w: Jurysdykcja, uznawanie orzeczeń sqdowych oraz ich wykonywanie w sprawach cywilnych $i$ handlowych. Rozporzadzenie Parlamentu Europejskiego i Rady (UE) Nr 1215/2012. Komentarz. Red. J. Gołaczyński. Warszawa 2015, kom. do art. 45; M.P. Wójcik, w: Komentarz... Red. A. Jakubecki, kom. do art. 1146; P. Rylski, w: Komentarz... Red. H. Dolecki, T. Wiśniewski, kom. do art. 1146; T. Ereciński, w: Komentarz... Red. T. Ereciński, kom. do art. 1146; A. Włosińska: Odmowa uznania zagranicznego orzeczenia sqdowego $w$ świetle postanowień konwencji lugańskiej. Kraków 2002, s. 201 i nast.; K. Zawada: Klauzula porzadku publicznego $w$ międzynarodowym postępowaniu cywilnym. „Nowe Prawo” 1979, nr 5, s. 74 i nast. 
nia wykonalności takiego orzeczenia jest sprzeczność z „podstawowymi zasadami porządku prawnego Rzeczypospolitej Polskiej"18. O potrzebie ingerencji za pomocą klauzuli porządku publicznego orzeka sąd w odrębnym postępowaniu. Wniosek może złożyć każdy kto ma interes prawny w ustaleniu, że orzeczenie sądu państwa obcego podlega albo nie podlega uznaniu (art. 1148 k.p.c.). Wniosek o stwierdzenie wykonalności (w przypadku wyroków nadających się do egzekucji) składa zainteresowany wierzyciel (art. 1151 k.p.c.). W postępowaniu tym, sąd bada m.in. czy zagraniczne orzeczenie nie jest sprzeczne z podstawowymi zasadami porządku prawnego RP (art. 1150 zd. 2 k.p.c.).

Uznawanie i wykonywanie orzeczeń wydawanych przez sądy innych państw członkowskich co do zasady podlega regulacjom prawa unijnego $^{19}$. Pomimo przyjęcia w wielu unijnych rozporządzeniach zasady automatycznego uznania i stwierdzenia wykonalności nie nastąpiło wyłączenie znanych wcześniej podstaw odmowy uznania lub stwierdzenia wykonalności. W nowym rozporządzeniu Bruksela I bis pozostały one bez zmian (art. 45 rozporządzenia) w stosunku do poprzednio obowiazującego rozporządzenia Bruksela I. Mimo pojawiajacych się w tym przedmiocie propozycji Komisji Europejskiej ${ }^{20}$, nie zdecydowano się jak na razie na rezygnację $\mathrm{z}$ klauzuli porządku publicznego $\mathrm{w}$ ramach brukselskiego reżimu uznawania i wykonywania orzeczeń. W rozporządzeniu Bruksela I bis pozostawiono zatem możliwość powoływania się na sprzeczność orzeczenia z podstawowymi zasadami prawa materialnego państwa, w którym orzeczenie zostało skierowane do uznania lub wykonania (materialna klauzula porządku publicznego), jak i na naruszenia gwarancji prawa do rzetelnego procesu (procesowa klauzula porządku publicznego).

${ }^{18}$ Zob. także art. 1150 k.p.c., w którym przenosi się podstawy odmowy uznania wskazane w art. $1146 \S 1$ i $§ 2$ (a zatem również klauzulę porządku publicznego) na grunt stwierdzenia wykonalności orzeczeń sądów państw obcych.

${ }^{19}$ Jeżeli orzeczenie mieści się w przedmiotowym zakresie zastosowania regulacji unijnych.

${ }^{20}$ Zob. art. 45-46 projektu nowego rozporządzenia Bruksela I przedstawionego przez Komisję Europejską w grudniu 2010 r.: COM(2010) 748, która proponowała zastąpienie ogólnej klauzuli porządku publicznego węższym ujęciem, nawiązującym do sprzeczności z podstawowymi zasadami leżącymi u podstaw prawa do rzetelnego procesu. Por. P. Beaumont, L. Walker: Recognition and enforcement of judgments in civil and commercial matters in the Brussels I Recast, and some lessons from it and the recent Hague Conventions for the Hague Judgments Project. "Journal of Private International Law" 2015, vol. 11, nr 1, s. 33. Co ciekawe, Komisja już w 1997 r. proponowała rezygnację z klauzuli porządku publicznego. Zob. A. Staudinger: The Public Policy Proviso in European Civil Procedural Law. "European Law Forum” 2004, nr 5, s. 274. 
Utrzymanie klauzuli porządku publicznego spotkało się z aprobata większości doktryny ${ }^{21}$. Rezygnacji z niej w unijnym systemie wzajemnego uznawania i wykonywania orzeczeń sprzeciwiała się także większość państw członkowskich UE ${ }^{22}$.

Przyjmuje się, że klauzula porządku publicznego stanowi ostateczny środek interwencji przeciwko obcemu orzeczeniu (ultima ratio) ${ }^{23}$. Znajduje ona zastosowanie tylko w szczególnych wypadkach.

$\mathrm{Na}$ tle rozporzadzenia Bruksela I bis, kontrola zagranicznego orzeczenia pod kątem jego zgodności z porządkiem publicznym odbywa się w odrębnym postępowaniu, którego przedmiotem jest ocena uznania lub stwierdzenia wykonalności orzeczenia (zob. art. 36 ust. 2, art. 45 i 46) albo w ramach postępowania dotyczącego innego przedmiotu, gdy odmowa uznania orzeczenia obcego sądu pojawi się jako kwestia wstępna, od której zależy rozstrzygnięcie sprawy głównej (art. 36 ust. 3) ${ }^{24}$. Odrębne postępowanie może zostać wszczęte na wniosek dłużnika, tj. osoby zainteresowanej odmowa uznania orzeczenia (art. 45 ust. 1) lub osoby, przeciwko której wystąpiono o wykonanie orzeczenia (art. 46), tudzież

${ }^{21}$ Zob. J. Fitchen, in: The Brussels I Regulation Recast. Eds. A. Dickinson, E. Lein. Oxford 2015, pkt 13.269 i nast.; J. Oster: Public Policy and Human Rights. "Journal of Private International Law" 2015, vol. 11, nr 3, s. 545; L. Tim mer: Abolition of Exequatur..., s. 131; M. Weller: Mutual Trust: In Search of the Future of European Union Private International Law. "Journal of Private International Law" 2015, vol. 11, no. 1, s. 83. Tak też na etapie dyskusji dotyczącej nowej wersji rozporządzenia Bruksela I np. H. Schack: The Misguided..., s. 1345 i nast. W toku dyskusji poprzedzającej przyjęcie przekształconej wersji rozporządzenia Bruksela I, postulowano jednak niekiedy likwidację klauzuli porządku publicznego jako podstawy odmowy uznania lub stwierdzenia wykonalności orzeczenia z innego państwa członkowskiego. W polskiej literaturze zob. np. P. Marcisz: Uznawanie orzeczeń w Unii Europejskiej. Między tożsamościa prawna państwa a otwarciem na obrót międzynarodowy. W: Prawo $w$ dobie globalizacji. Red. T. Giaro. Warszawa 2011, s. 126-132 (który wskazuje, że utrzymywanie klauzuli narusza istotę zobowiązania traktatowego państw członkowskich). Por. również literaturę zagraniczna cytowana przez P. Hay: Recognition of a Recognition Judgment Within the European Union: „Double Exequatur” and the Public Policy Barrier. In: Resolving International Conflicts: Liber Amicorum Tibor Várady. Eds. P. Hay, L. Vékás, Y. Elkana, N. Dimitrijevic. Budapest 2009, s. 62.

${ }^{22}$ Zob. J. Fitchen, in: Brussels I... Eds. A. Dickinson, E. Lein, pkt 13.272.

${ }^{23}$ Tak np. P. Grzegorczyk: Stosowanie..., s. 22; Ł. Goździaszek, w: Komentarz... Red. J. Gołaczyński, s. 213. W literaturze zagranicznej tak np. A. Staudinger: The Public Policy..., s. 273.

${ }^{24}$ Por. H. Schack: The Misguided..., s. 1345; P. Franzina, in: Brussels I... Eds. A. Dickinson, E. Lein, 2015, pkt. 13.02-13.93; P. Wautelet, in: Brussels I Regulation. Eds. U. Magnus, P. Mankowski. Ed. 2. München 2012, s. 640—644. 
na wniosek wierzyciela, tj. osoby zainteresowanej stwierdzeniem, że nie zachodza podstawy do odmowy uznania orzeczenia (art. 36 ust. 2) ${ }^{25}$.

Klauzula porządku publicznego została również zachowana w innych rozporządzeniach unijnych poświęconych jurysdykcji sądów w sprawach cywilnych oraz uznawaniu i wykonywaniu orzeczeń ${ }^{26}$. Zrezygnowano natomiast z klauzuli jako podstawy odmowy uznania i wykonania orzeczenia w rozporządzeniach poświęconych szczególnego rodzaju postępowaniom ustanowionym w celu przyspieszenia obrotu i wykonywania niektórych rodzajów rozstrzygnięc ${ }^{27}$.

\section{Zagadnienie równoległego uprawnienia orzeczeń zatwierdzających w obcych porządkach prawnych}

Zagadnienie dopuszczalności uznania lub stwierdzenia wykonalności orzeczeń zatwierdzających jest przedmiotem dyskusji i kontrowersji. $\mathrm{Z}$ uwagi na odmienne zasady prawa procesowego, zagadnienie jest nieco inaczej traktowane w państwach kontynentalnej i anglosaskiej kultury prawnej.

W kontynentalnej doktrynie międzynarodowego postępowania cywilnego od dawna dominuje przekonanie, że orzeczenia zatwierdzające nie

${ }^{25}$ Postępowanie z wniosku wierzyciela określa się czasem mianem „uprzedniego powództwa o ustalenie” (pre-emptive declaration). Na tle rozporządzenia Bruksela I bis środek tego typu nie dotyczy stwierdzenia wykonalności. Tak J. Fitchen, in: Brussels I... Eds. A. Dickinson, E. Lein, pkt 13.258. Na podstawie art. 36 ust. 2 wierzyciel może natomiast dochodzić stwierdzenia, że orzeczenie obcego sądu podlega uznaniu.

${ }^{26}$ Zob. art. 40 lit. a rozporządzenia spadkowego; art. 24 lit. a rozporządzenia alimentacyjnego; art. 22 lit. a rozporządzenia Bruksela II bis. Zob. również art. 33 rozporządzenia Parlamentu Europejskiego I Rady (UE) 2015/848 z dnia 20 maja 2015 r. w sprawie postępowania upadłościowego (wersja przekształcona). Dz.Urz. UE L 141 z 5.06.2015, s. 19 (jako podstawa odmowy uznania postępowania upadłościowego wszczętego w innym państwie członkowskim). Por. także art. 37 lit. a rozporządzenia dotyczącego majątkowych ustrojów małżeńskich oraz art. 37 lit. rozporządzenia dotyczącego skutków majątkowych związków partnerskich (te ostatnie nie obowiązują w Polsce).

${ }_{27} \mathrm{Tj}$. w rozporządzeniu $\mathrm{nr} 805 / 2004 \mathrm{z}$ dnia 21 kwietnia 2004 r. w sprawie utworzenia europejskiego tytułu egzekucyjnego dla roszczeń bezspornych, rozporządzeniu nr 1896/2006 z dnia 12 grudnia 2006 r. ustanawiającego postępowanie w sprawie europejskiego nakazu zapłaty oraz rozporządzeniu nr 861/2007 z dnia 11 lipca 2007 r. ustanawiającego europejskie postępowanie w sprawie drobnych roszczeń. 
podlegaja uznaniu ani stwierdzeniu wykonalności w innym państwie, zgodnie $\mathrm{z}$ maksyma exequatur sur exequatur ne vaut ${ }^{28}$. Przedmiotem orzeczenia zatwierdzającego jest bowiem jedynie uznanie lub stwierdzenie wykonalności wyroku na terytorium określonego państwa ${ }^{29}$. Nakierowane jest ono wyłącznie na wywołanie skutków na terenie państwa, którego sąd orzeka o uznaniu lub stwierdzeniu wykonalności. Innymi słowy, skutki orzeczenia, którego przedmiotem jest uznanie lub stwierdzenie wykonalności zagranicznego wyroku są wyłącznie lokalne ${ }^{30}$. Jest to szczególnie wyraźne w przypadku orzeczeń podlegających wykonaniu. Wykonanie implikuje wszakże wykorzystanie państwowego aparatu przymusu. Exequatur stanowi zezwolenie na wykorzystanie tego aparatu przez organy danego państwa (egzekucję przeciwko dłużnikowi z użyciem siły). Skutki tego typu wiążą się z kontrolą sprawowaną przez sądy danego państwa $\mathrm{w}$ odniesieniu do korzystania ze środków przymusu na jego terytorium. Sa w rezultacie ściśle powiązane z terytorium danego państwa. W mojej ocenie, również jednak orzeczenie stwierdzające uznanie zagranicznego wyroku ma skutek ograniczony wyłacznie do własnego terytorium państwa sądu delibacyjnego. Skutki takiego orzeczenia nie mogą być rozszerzane na obszar innych państw ${ }^{31}$, ponieważ nie można przyznawać orzeczeniu szerszych skutków niż ono samo wyraża ${ }^{32}$. Istotą zaś orzeczenia uznającego zagraniczny wyrok jest stwierdzenie, że nadaje się on do uznania na terytorium danego państwa, gdyż nie zacho-

${ }^{28}$ Pogląd ten uzasadnił w szczególności G. Kegel: Exequatur sur exequatur ne vaut. In: Festschrift für Wolfram Müller-Freienfels. Eds. A. Dieckmann, R. Frank, H. Hanisch, S. Simitis. Baden-Baden 1986, s. 377 i to na jego pracę powołuja się z reguły autorzy sprzeciwiajacy się uznawaniu i wykonywaniu orzeczeń zatwierdzajacych. Zob. T. Einhorn: The Recognition..., s. 57; P. Wautelet, in: Brussels I Regulation. Eds. P. Mankowski, U. Magnus. Eds. 1. München 2007, s. 545; P. Hay: Recognition of a Recognition Judgment Within..., s. 146. Autorstwo samej formuły exequatur sur exequatur ne vaut przypisuje się jednak francuskiemu sędziemu Gavalda (orz. Tribunal civil de la Seine, 6.12.1934. "Journal du Droit International" 1935, s. 113). Zob. B. Ula necki: Exequatur sur exequatur vaut dans l'ordre international européen?, http:// ileurope.blogspot.com/2009/12/exequatur-sur-exequatur-vaut-dans.html [Data dostępu: 20.07.2018 r.). W orzecznictwie państw kontynentalnych możliwość uznania lub stwierdzenia wykonalności orzeczenia zatwierdzającego zanegował np. Tribunal de Grande Instance de Paris w orz. z 30.10.1968. "Journal du Droit International" 1970, s. 941.

${ }^{29}$ T. Einhorn: The Recognition..., s. 56; B. Ulanecki: Exequatur... W polskiej literaturze tak: K. Weitz: Konwencja..., s. 83; A. Włosińska: Odmowa..., s. 116.

${ }^{30} \mathrm{~K}$. Kerameus: Enforcement in the international context. "Recueil des cours" 1997, vol. 264, s. 473.

${ }^{31}$ Zob. opinię Rzecznika Generalnego Lenza z 16.09.1993 w sprawie C-129/92 Owens Bank Ltd v Fulvio Bracco and Bracco Industria Chimica SpA, pkt 21.

${ }^{32}$ Tak P. Hay: Recognition of a Recognition Judgment under Brussels I, http://conflictoflaws.net, 8.09.2008 [Data dostępu: 24.07.2018 r.], który podnosi: It seems axiomatic not to give a judgment greater force than it itself claims. 
dzą negatywne ku temu przesłanki (np. że nie narusza on podstawowych zasad porządku prawnego tego państwa).

Konsekwencją braku równoległego uprawniania orzeczeń zatwierdzających jest, że wierzyciel, który uzyskał korzystny dla siebie wyrok w państwie pochodzenia musi dochodzić uznania lub stwierdzenia wykonalności tego wyroku w każdym kolejnym państwie osobno. Uznanie lub stwierdzenie wykonalności odbywa się zawsze w odniesieniu do pierwotnego orzeczenia merytorycznego ${ }^{33}$.

W państwach common law przyjmuje się odmienne założenia procesowe, co ma wpływ także na sposób traktowania omawianego zagadnienia. Mianowicie, tradycja procesowa tych krajów zakłada, że zagraniczne orzeczenie stanowi jedynie roszczenie, które może być wykonane po uzyskaniu orzeczenia w stosownym postępowaniu (tzw. actio judicati). W rezultacie powstaje orzeczenie jak każde inne ${ }^{34}$. Skoro orzeczenie to rozstrzyga $\mathrm{w}$ przedmiocie roszczenia, to przynajmniej teoretycznie mogłoby być następnie przedmiotem uznania lub stwierdzenia wykonalności w innych państwie ${ }^{35}$.

Pomimo to, kwestię ewentualnego równoległego uprawnienia orzeczeń zatwierdzających rozwiązuje się w Anglii podobnie jak na kontynencie. Przyjmuje się mianowicie, że sąd rozstrzygający o uznaniu lub stwierdzeniu wykonalności powinien zbadać pierwotne merytoryczne orzeczenie sądu państwa jego pochodzenia. Nie może on jedynie oprzeć się na orzeczeniu zatwierdzającym wydanym w państwie, w którym pierwotne orzeczenie już zostało uznane (lub jego wykonalność została tam stwierdzona) $)^{36}$.

Kwestię równoległego uprawnienia rozstrzyga się natomiast odmiennie w USA. Wprawdzie amerykański Sąd Najwyższy w sprawie Baker $v$. General Motors Corp. wyraził przekonanie, zgodnie z którym „instrumenty wykonawcze nie podróżują" (,enforcement measures do not travel") ${ }^{37}$, tj. wywołuja skutki jedynie w państwie wykonania, jednakże stwierdzenie to dotyczyło przede wszystkim procesowych reguł (metod), na podstawie których odbywa się wykonanie orzeczenia, a nie oceny przesłanek uznania lub stwierdzenia wykonalności orzeczenia spoza USA (takich jak

${ }^{33}$ K. Kerameus: Enforcement..., s. 473.

${ }^{34}$ B. Ulanecki: Exequatur..., z powołaniem na Dicey, Morris \& Collins, The Conflict of Laws. London 2006, s. 570.

${ }^{35}$ Zob. E. Scoles, P. Hay, P. Borchers, S. Symeonides: Conflict of Laws. 4 Ed. Thomson West 2004, § 24.3 i nast.

${ }^{36}$ T. Einhorn: The Recognition..., s. 57.

${ }^{37}$ Zob. orzeczenia amerykańskiego Sądu Najwyższego w sprawach Baker v. General Motors Corp., 522 U.S. 222 (1998) oraz McElmoyle ex rel. Bailey v. Cohen, 13 Pet. 312, 325 (1839). 
klauzula porządku publicznego). Orzeczenie zatwierdzajace wyrok sądu państwa trzeciego wydane w jednym stanie korzysta z klauzuli Full Faith and Credit na terenie całych Stanów Zjednoczonych. Uznanie zatem orzeczenia spoza USA w jednym stanie umożliwia jego uznanie i wykonanie $\mathrm{w}$ innych stanach bez ponownego badania przesłanek uznania ${ }^{38}$. Kwestie te objęte sa powaga rzeczy osądzonej. Wyjątek stanowi jednak ocena pod katem zgodności z lokalnym porządkiem publicznym stanu docelowego, która nie jest objęta powagą rzeczy osądzonej (res iudicata) ${ }^{39}$. Sąd stanu docelowego może zatem badać czy uznanie orzeczenia sądu państwa trzeciego nie jest sprzeczne z jego własnym porządkiem publicznym, nawet jeżeli tego typu badanie odbyło się już w stanie pośrednim (choć pod kątem zgodności z porządkiem publicznym tamtego stanu).

W Polsce, w kwestii koncepcji równoległego uprawnienia miał okazję wypowiedzieć się już Są Najwyższy, choć w kontekście wniosku o uznanie orzeczenia zagranicznego sądu oddalającego skargę o uchylenie wyroku sądu polubownego. Chodziło zatem o uznanie orzeczenia sądu powszechnego wypowiadającego się na temat braku podstaw do uchylenia wyroku sądu polubownego (a nie wyroku sądu powszechnego) ${ }^{40}$. Sąd Najwyższy doszedł do wniosku, że orzeczenie tego typu w ogóle nie podlega uznaniu na podstawie art. $1145 \S 1$ k.p.c., ponieważ nie ma tzw. zdatności uznaniowej. Zdaniem SN nie ma podstaw aby poprzez takie uznanie ograniczać swobodę sądu decydującego w uznaniu wyroku arbitrażowego wydanego za granica (tj. sądu delibacyjnego do którego wnioskodawca może zwrócić się o uznanie w Polsce bezpośrednio wyroku arbitrażowego). Sąd Najwyższy odmówił zatem orzeczeniu zagranicznego sądu oddalającego skargę o uchylenie wyroku sądu polubownego równoległego

${ }^{38}$ S.I. Strong: Recognition and Enforcement of Foreign Judgements in US Courts: Problems and Possibilities. "Review of Litigation" 2014, vol. 33, s. 78; P. Hay: Recognition of a Recognition Judgment Within..., s. 158.

${ }^{39}$ P. Hay: Recognition of a Recognition Judgment Within..., s. 159.

${ }^{40}$ Ściślej chodziło o rozstrzygnięcie zagranicznego sądu stwierdzające, że skarga o uchylenie orzeczenia sądu arbitrażowego podlega oddaleniu z uwagi na brak legitymacji procesowej skarżącego (ponieważ zdaniem zagranicznego sądu nie był on związany wyrokiem arbitrażowym). Trudno tu zatem mówić o orzeczeniu zatwierdzającym wyrok sądu arbitrażowego. Wnioskodawca (skarżący) chciał jednak uznania w Polsce tego rozstrzygnięcia, ponieważ zmierzał do przeniesienia do Polski wniosku, że nie jest związany wyrokiem arbitrażowym. Sąd Najwyższy odmówił mu takiej możliwości, przyjmując, że rozstrzygnięcie zagranicznego sądu oddalające skargę o uchylenie wyroku arbitrażowego nie podlega w Polsce uznaniu. Zob. szerzej M. Zachariasiewicz: Glosa do orz. SN $z 6$ listopada 2009 r. W: Diagnoza arbitrażu. Funkcjonowanie prawa o arbitrażu i kierunku postulowanych zmian. Red. B. Gessel-Kalinowska vel Kalisz. Wrocław 2014, s. 446 i nast. 
uprawnienia, z którego można byłoby korzystać w Polsce. Rozstrzygnięcie to słusznie spotkało się z aprobatą w doktrynie ${ }^{41}$.

Wydaje się, że przypadek orzeczenia zatwierdzającego wyrok sądu powszechnego państwa trzeciego (tudzież odmawiajacy takiego zatwierdzenia) należy traktować analogicznie. Rozstrzygnięcie tego typu również nie powinno podlegać uznaniu na podstawie art. 1145 k.p.c.

\section{Równoległe uprawnienie orzeczeń zatwierdzających na tle unijnego reżimu uznawania i wykonywania orzeczeń}

Uznanie i wykonanie orzeczeń wydanych przez sądy państw członkowskich podlega co do zasady przepisom prawa unijnego. Należy rozważyć, jak przedstawia się kwestia ewentualnego równoległego uprawnienia orzeczeń zatwierdzających w kontekście unijnego reżimu swobodnego przepływu orzeczeń. Innymi słowy, musimy się zastanowić czy orzeczenia zatwierdzające wydane przez sądy państw członkowskich mogą być przedmiotem uznania lub stwierdzenia wykonalności w innych państwach członkowskich.

$\mathrm{Na}$ początek warto przypomnieć, że możemy mieć tu do czynienia z dwoma rodzajami przypadków. Po pierwsze, chodzi o sytuacje, w których pierwotny wyrok wydany został na terenie państwa trzeciego, spoza UE (np. w USA) i następnie został uznany lub stwierdzono jego wykonalność w państwie członkowskim (np. we Francji). Po drugie, możemy mieć także do czynienia z przypadkami, w których wyrok wydany przez są państwa członkowskiego (np. w Belgii) został uznany lub stwierdzono jego wykonalność w innym państwie członkowskim (np. we Francji). W obydwu przypadkach orzeczenie zatwierdzające (stwierdzajace uznanie lub wykonalność) pochodzi od sądu państwa członkowskiego. Powstaje pytanie, czy takie orzeczenie podlega uznaniu lub stwierdzeniu wykonalności w innych państwach Unii na podstawie reżimu ustanowionego prawem UE, co implikowałoby m.in., że korzysta ono ze swobodnego przepływu orzeczeń.

${ }^{41}$ M. Tomaszewski: Glosa..., s. 689; M. Zachariasiewicz: Glosa..., s. 446 i nast. Przeciwko możliwości stwierdzenia wykonalności zagranicznego orzeczenia, którego przedmiotem jest nadanie exequatur wyrokowi arbitrażowemu, opowiedział się również Ł. Błaszczak: Wyrok..., s. 438. 
W doktrynie dominowało jak dotąd stanowisko, zgodnie z którym również na tle unijnego reżimu uznawania i wykonywania orzeczeń (w tym zwłaszcza $\mathrm{w}$ sprawach cywilnych i handlowych) nie podlega uznaniu i stwierdzeniu wykonalności orzeczenie zatwierdzające, tj. takie którego przedmiotem jest jedynie uznanie lub stwierdzenie wykonalności merytorycznego wyroku sądu innego państwa ${ }^{42}$. Dotyczy to zarówno przypadków, w których chodzi o orzeczenie zatwierdzające wyrok pochodzący z innego państwa członkowskiego, jak i wyrok wydany przez sąd spoza Unii Europejskiej ${ }^{43}$.

Zagadnienie dopuszczalności uznania lub stwierdzenia wykonalności orzeczeń zatwierdzających wiąże się z definicja „orzeczenia” na tle unijnego reżimu uznawania i wykonywania. Zgodnie $\mathrm{z}$ art. 2 lit. a rozporządzenia Bruksela I bis: „orzeczenie oznacza każde orzeczenie wydane przez sąd państwa członkowskiego - niezależnie od tego, jak zostanie określone - w tym wyrok, postanowienie, nakaz, nakaz egzekucyjny oraz postanowienie w przedmiocie ustalenia kosztów postępowania wydane przez urzędnika sądowego"44. Definicja ta jest stosunkowo szeroka i obejmuje co do zasady wszystkie merytoryczne rozstrzygnięcia sądów państw członkowskich ${ }^{45}$. Przyjmuje się jednak, że definicja ta nie obejmuje orzeczeń, których przedmiotem jest jedynie uznanie lub stwierdzenie wykonalności wyroku pochodzącego z innego państwa ${ }^{46}$. Orzeczenia

${ }^{42} \mathrm{~W}$ polskiej literaturze tak A. Włosińska: Odmowa..., s. 116.

${ }^{43}$ Zob. opinię Rzecznika Generalnego Lenza z 16.09.1993 r. w sprawie C-129/92 Owens Bank Ltd v Fulvio Bracco and Bracco Industria Chimica SpA, pkt. 20-22, 80; P. Wautelet, in: Brussels I ... (ed. 1). Eds. P. Mankowski, U. Magnus, s. 545; P. Hay: Recognition of a Recognition Judgment Within ..., s. 146.

${ }^{44}$ Por. nieomalże identyczne brzmienie art. 32 starego rozporządzenia Bruksela I, art. 25 konwencji brukselskiej z 1968 r.

${ }^{45} \mathrm{Na}$ marginesie można zauważyć, że unijny nakaz uznawania i stwierdzania wykonalności orzeczeń pochodzących z innych państw członkowskich UE obejmuje negatywne rozstrzygnięcia w przedmiocie jurysdykcji krajowej. Orzeczeniem w rozumieniu przepisów rozporządzenia Bruksela I bis, a więc takim, które podlega uznaniu na podstawie unijnych przepisów, jest zatem także takie, w którym sąd innego państwa członkowskiego odrzucił pozew z uwagi na brak jurysdykcji krajowej w sprawie. Dotyczy to również przypadków, w których sąd państwa członkowskiego uznaje się za niewłaściwy do rozpoznania sprawy ze względu na istnienie klauzuli jurysdykcyjnej. W konsekwencji sąd, do którego zwrócono się o uznanie orzeczenia jurysdykcyjnego, w którym sąd innego państwa członkowskiego uznał się za niewłaściwy do rozpoznania sprawy ze względu na istnienie klauzuli jurysdykcyjnej, jest związany ustaleniem w przedmiocie ważności tej klauzuli. Zob. wyrok TSUE z 15.11.2012 r. w sprawie C-456/11 Gothaer Allgemeine Versicherung AG i in. v. Samskip GmbH. ECLI:EU:C:2012:719.

${ }^{46}$ Tak na tle starego rozporządzenia Bruksela I: P. Wautelet, in: Brussels I... (ed. 1). Eds. P. Mankowski, U. Magnus, s. 545; T. Einhorn: The Recognition..., s. 57; na tle konwencji brukselskiej z 1968 r.: A. Włosińska: Odmowa..., s. 116. 
tego typu nie korzystaja zatem z unijnego nakazu wzajemnego uznawania orzeczeń pomiędzy państwami członkowskimi.

Wśród argumentów przemawiających za odrzuceniem możliwości uznawania (stwierdzania wykonalności) orzeczeń zatwierdzających wymieniano podobne do wysuwanych za zasada exequatur sur exequatur ne vaut $\mathrm{w}$ ogóle. Przede wszystkim wskazywano, że decyzja sądu danego państwa o uznaniu na jego terytorium określonego wyroku, bądź też o stwierdzeniu jego wykonalności, ma ściśle lokalny, terytorialny charakter $^{47}$. Ponadto, podnoszono, że wierzyciel nie ma interesu prawnego $\mathrm{w}$ dochodzeniu uznania lub stwierdzenia wykonalności orzeczenia zatwierdzającego, ponieważ może dochodzić uznania lub stwierdzenia wykonalności pierwotnego wyroku ${ }^{48}$. Wreszcie zauważano, że dopuszczenie możliwości uznania (stwierdzenia wykonalności) orzeczenia zatwierdzajacego mogłoby prowadzić od obejścia podstawowych zasad porządku publicznego w państwie, w którym uznania lub wykonania się dochodzi, poprzez pośrednie wprowadzenie do tego porządku prawnego pierwotnego wyroku, który nie mógł stać się przedmiotem kontroli za pomoca klauzuli porządku publicznego (zob. szerzej niżej).

Współcześnie, na tle nowego rozporządzenia Bruksela I bis pojawiają się jednak dwa rodzaje okoliczności, które należy rozważyć przed udzieleniem ostatecznej odpowiedzi na pytanie o dopuszczalność uznania lub stwierdzenia wykonalności orzeczeń zatwierdzających. W pierwszej kolejności trzeba zauważyć, że w świetle przepisów nowego rozporządzenia Bruksela I bis nie ma już konieczności uzyskiwania orzeczenia stwierdzającego wykonalność w państwie członkowskim (exequatur), w którym wierzyciel chce egzekwować korzystne dla siebie rozstrzygnięcie. Zgodnie bowiem z art. 38 stwierdzenie wykonalności następuje „bez potrzeby stwierdzania jego wykonalności”, czyli automatycznie (ex lege). Ważny argument podnoszony przeciwko równoległemu uprawnieniu - oparty na ściśle terytorialnym, lokalnym charakterze exequatur - traci zatem na sile. Exequatur w ogóle przestaje być bowiem konieczne.

Powyższe oznacza, że w normalnym toku rzeczy brak jest jakiegokolwiek rozstrzygnięcia sądu państwa, w którym wierzyciel dochodzi wykonania, które mogłoby być przedmiotem dalszego stwierdzenia wykonal-

${ }^{47}$ Tak R.G. Lenz w Opinii w sprawie Owens Bank, pkt 21, którego zdaniem na tle konwencji brukselskiej z 1968 r. przesądzało o tym także samo brzmienie art. 31. Podobnie jak na tle art. 31 konwencji, brzmienie art. 38 rozporządzenia Bruksela I sugerowało lokalny charakter orzeczenia stwierdzającego wykonalność wyroku z innego państwa członkowskiego („Orzeczenia wydane w jednym Państwie Członkowskim [...] będą wykonywane w innym Państwie Członkowskim, jeżeli ich wykonalność w nim zostanie stwierdzona [podkr. M.Z.]".

${ }^{48}$ A. Włosińska: Odmowa..., s. 117. 
ności. Jedynie jeśli kwestia stwierdzenia wykonalności jest sporna (czy zachodzą przesłanki jego odmowy) to może zapaść rozstrzygnięcie przed sądem w państwie wykonania. Jak zaznaczono już wcześniej, odbywa się to $\mathrm{w}$ odrębnym postępowaniu. To właśnie rozstrzygnięcie określamy $\mathrm{w}$ tym miejscu tu jako orzeczenie zatwierdzajace. W mojej ocenie także ono ma ściśle lokalny charakter i nie podlega stwierdzeniu wykonalności w innych państwach członkowskich.

Drugą kwestia, którą trzeba rozważyć, jest pojawiający się czasem argument, zgodnie z którym za uznawaniem lub stwierdzaniem wykonalności orzeczeń zatwierdzających na tle przepisów unijnych przemawia zasada swobodnego przepływu orzeczen ${ }^{49}$. Orzeczenia wydane przez sądy państw członkowskich korzystają bowiem w innych państwach członkowskich ze szczególnego nakazu wzajemnego uznawania. $\mathrm{Na}$ skutek rozwijania przez kilka dekad współpracy sądowej w sprawach cywilnych i handlowych, w tym w orzecznictwie Trybunału Sprawiedliwości, nakaz ten jest niezwykle silny. Wyraża on określonego rodzaju lojalność w stosunku do państw będących członkami określonej wspólnoty, połączonej politycznymi, ekonomicznymi oraz kulturowymi więzami i ukonstytuowanej wokół wspólnych wartości podstawowych. Nakaz ten uzasadniony jest zaufaniem przejawianym w stosunku do wymiarów sprawiedliwości innych członków danej wspólnoty państw. Unijny nakaz wzajemnego uznawania jest w konsekwencji coraz częściej porównywany do amerykańskiej Full Faith and Credit Clause znajdującej zastosowanie do uznawania i wykonywania orzeczeń sądowych pomiędzy poszczególnymi stanami USA ${ }^{50}$. Można zatem podnosić, że państwa członkowskie powinny sobie ufać także w odniesieniu do omawianej kwestii, tj. że sąd delibacyjny innego państwa członkowskiego, który wydał orzeczenie zatwierdzające dokonał właściwej i wystarczajacej kontroli wyroku pochodzącego z jeszcze innego państwa ${ }^{51}$. Można także argumentować, że wyrok z państwa trzeciego (spoza UE) przekształca się w ten sposób w orzeczenie unijne ${ }^{52}$.

W mojej ocenie, argumenty te nie sa wystarczajaco przekonujące aby zaakceptować równoległe uprawnienie orzeczeń zatwierdzających wydawanych przez sądy innych państw członkowskich. Także bowiem w unijnym obszarze prawnym sąd państwa docelowego uznania lub wykonania musi mieć zagwarantowaną możliwość badania czy pierwotny wyrok na-

${ }^{49}$ B. Ulanecki: Exequatur...; P. Hay: Recognition of a Recognition Judgment under Brussels I?

${ }^{50}$ Zob. M. Zachariasiewicz: Klauzula..., s. 113 i nast. oraz literatura tam cytowana.

${ }^{51}$ P. Hay: Recognition of a Recognition Judgment under Brussels I?

${ }^{52}$ Ibidem. 
daje się do uznania lub wykonania, a w szczególności, czy skutki tego uznania lub wykonania byłyby zgodne z podstawowymi zasadami jego porządku prawnego (klauzula porządku publicznego). Kwestia ta będzie przedmiotem szczegółowej analizy niżej.

Nieco na marginesie głównych rozważań, można zauważyć, że brak równoległego uprawnienia orzeczeń zatwierdzajacych nie oznacza, że nie jest możliwe wszczęcie postępowania o stwierdzenie wykonalności wyroku równocześnie w kilku państwach. Przeciwnie - wierzyciel może złożyć wniosek o uznanie lub stwierdzenie wykonalności korzystnego dla siebie wyroku w kilku państwach jednocześnie. Fakt złożenia już w określonym państwie wniosku nie stanowi przeszkody dla dochodzenia praw $\mathrm{z}$ wyroku równocześnie $\mathrm{w}$ innym państwie ${ }^{53}$. Zasada przeciwdziałania równoległym postępowaniom (lis pendens) wyrażona w art. 29 rozporzadzenia Bruksela I bis nie znajduje tu zastosowania ${ }^{54}$. Wynika to właśnie z lokalnego charakteru orzeczenia stwierdzajacego uznanie lub wykonalność wyroku w danym państwie. Skoro takie orzeczenie dotyczy wyłącznie jednego państwa (tylko na terenie jednego państwa wywołuje skutki prawne) to nie ma przeszkód aby w innych państwach równocześnie toczyły się postępowania, które będą miały analogiczny przedmiot (ale w stosunku do terytorium tych państw). Jest to inny przedmiot identycznych postępowań ${ }^{55}$. Niedopuszczalność uznania lub stwierdzenia wykonalności zagranicznych orzeczeń zatwierdzających określony wyrok harmonizuje zatem z dopuszczalnością równoległego toczenia się postępowań o uznanie lub stwierdzenie wykonalności tego wyroku w kilku państwach.

\section{Klauzula porządku publicznego a uznanie lub stwierdzenie wykonalności orzeczeń zatwierdzających}

Najważniejszym argumentem przemawiającym za odrzuceniem możliwości uznawania orzeczeń zatwierdzających jest - jak sygnalizowaliśmy już wcześniej - potrzeba zagwarantowania dla sądu państwa, w którym pierwotny wyrok zagranicznego sądu ma wywoływać skutki prawne (państwa docelowego), kompetencji do kontrolowania zgodności

\footnotetext{
${ }^{53}$ Tak, na tle konwencji lugańskiej z 1988, K. Weitz: Konwencja..., s. 82-83.

${ }^{54}$ K. Weitz: Konwencja..., s. 83 (na tle konwencji lugańskiej z 1988 r.).

${ }^{55}$ Ibidem.
} 
tego wyroku z własnym porządkiem publicznym ${ }^{56}$. Sąd państwa docelowego pozbawiony byłby zaś takiej kontroli, gdyby do uznania lub stwierdzenia wykonalności przedstawiano jedynie orzeczenie zatwierdzające wydane w państwie pośrednim. Dzieje się tak ponieważ przedmiotem kontroli sądu państwa docelowego mogłyby być jedynie okoliczności dotyczące orzeczenia zatwierdzającego i postępowania, które toczyło się przed tym sądem, ale już nie te, które dotyczą samego pierwotnego wyro$\mathrm{ku}$ wydanego w państwie pochodzenia ${ }^{57}$. Skoro zaś przesłanką odmowy uznania lub wykonania pozostaje (także na tle nowego rozporządzenia Bruksela I bis przeciwko rozstrzygnięciom z innych państw członkowskich) sprzeczność orzeczenia z podstawowymi zasadami porządku publicznego, to sąd państwa docelowego musi mieć możliwość oceny właściwego merytorycznego wyroku pod katem zgodności z tymi zasadami, a nie jedynie orzeczenia zatwierdzającego.

Gdyby uznaniu lub wykonaniu podlegało także orzeczenie zatwierdzające to wierzyciel miałby możliwość polegać na tego typu orzeczeniu nie tylko w kraju, w którym zostało ono wydane ale także w innych państwach. Pojawiłoby się zatem ryzyko obejścia zasad porządku publicznego państwa docelowego, poprzez uprzednie uzyskanie exequatur w państwie pośrednim. Może się bowiem zdarzyć tak, że wyrok państwa X nie narusza porządku publicznego państwa A, gdzie w konsekwencji zostaje uznany i wykonany, ale narusza porządek publiczny państwa B. Stosując praktykę, która określić można jako szczególną postać forum shopping, wierzyciel mógłby dokonywać próby swoistego „wyprania” orzeczenia w państwie A, gdzie jest ono do zaakceptowania i tym samym uniknąc kontroli w państwie $\mathrm{B}$, z perspektywy którego jest ono sprzeczne z porządkiem publicznym ${ }^{58}$.

Jak wspomniano już wyżej, nic w powyższym rozumowaniu nie zmienia system automatycznego uznawania i stwierdzania wykonalności przyjęty w rozporządzeniu Bruksela I bis. Tak długo jak w państwie A nie zostało wydane orzeczenie zatwierdzajace (a nie ma takiej konieczności), sytuacja w państwie B jest analogiczna do sytuacji w państwie A, tj. wyrok z państwa X może podlegać uznaniu i stwierdzeniu wykonal-

${ }^{56}$ Podobnie P. Wautelet, in: Brussels I... (ed. 1). Eds. P. Mankowski, U. Magnus, s. 545; P. Hay: Recognition of a Recognition Judgment Within..., s. 144-146.

${ }^{57}$ Tak - choć w odniesieniu do zagadnienia uznawania i wykonywania orzeczeń sądów powszechnych zatwierdzających wyroki sądów arbitrażowych - L. Silberman, M. Scherer: Forum..., s. 334; M.L. Roth: Recognition..., s. 589; T. Einhorn: The Recognition..., s. 59.

${ }_{58}$ Zob. Morgan Stanley \& Co International Ltd v Pilot Lead Investments Ltd [2006] 4 HKC 93; [2006] HKCFI 430 (High Court of the Hong Kong Special Administrative Region); Clarke v. Fennoscandia Ltd [2004] SC 197 (Scottish Outer House). 
ności ex lege (w zakresie $\mathrm{w}$ jakim chodzi o wyrok wydany w państwie członkowskim Unii), albo po wydaniu stosownego rozstrzygnięcia przez sąd państwa B - w każdym przypadku przy założeniu, że nie zachodzą negatywne przesłanki uznania i wykonania. Jeżeli natomiast w państwie A wydane zostanie orzeczenie zatwierdzajace wyrok sądu państwa $\mathrm{X}$ (także gdy chodzi o państwo nieczłonkowskie) to nie wywołuje ono skutków poza terytorium państwa A. Sąd państwa B zachowuje swobodę w ocenie, czy wyrok sądu państwa X nadaje się do uznania lub wykonania w państwie $B$.

W obszarze materialnoprawnego porządku publicznego, omawiany problem może się pojawić zwłaszcza w przypadku istotnych różnic pomiędzy zasadami porządku prawnego przyjętymi w państwie A i w państwie B. Taka sytuacja zachodzić będzie stosunkowo rzadko jeżeli obydwa państwa należą do Unii Europejskiej. Także jednak i tu możemy się z nią spotkać. Dobrym przykładem jest sposób traktowania odszkodowań o funkcji penalnej dochodzonych w prywatnym procesie (punitive damages), znanych w najdalej idącej postaci w USA. Amerykańskie punitive damages wywołuja na kontynencie europejskim kontrowersje. Odszkodowanie tego typu może wielokrotnie przekraczać wysokość szkody. Służy ono bowiem nie tyle zrekompensowaniu szkód pokrzywdzonemu lecz ukaraniu sprawcy deliktu, który zachował się w sposób szczególnie naganny ${ }^{59}$.

W większości państw Unii odrzuca się możliwość dochodzenia odszkodowań karnych i dla wielu państw jest to na tyle istotne, że gotowe sa interweniować za pomoca klauzuli porządku publicznego w celu odmowy zastosowania prawa obcego przewidującego punitive damages lub odmowy stwierdzenia wykonalności orzeczenia zasądzającego tego typu odszkodowanie ${ }^{60}$. Stopień niechęci do punitive damages jest jednak

${ }^{59}$ Zob. np. Ch. Calleros: Punitive Damages, Liquidated Damages, and Clauses Pénales In Contract Actions: A Comparative Analysis of the American Common Law and the French Civil Code. "Brooklyn Journal of International Law" 2006, vol. 32, s. 7879; J.Y. Gotanda: Punitive Damages: A Comparative Analysis. "Columbia Journal of Transnational Law" 2004, vol. 42, s. 391 i nast.

${ }^{60}$ W orz. z 4.06.1992, ZWI, 1992, s. 1256 niemiecki BGH odmówił uznania orzeczenia amerykańskiego sądu w części zasądzającej na rzecz powoda punitive damages w wysokości 400 tys. \$ za molestowanie seksualne; podobnie we Włoszech Corte Cassazione w orz. z 19.01.2007 r. w sprawie Parrot v. Fimez, „Foro Italiano” nr 1183 orzekł, że punitive damages sa sprzeczne z włoskim porządkiem publicznym. Włoski Corte Cassazione zmienił jednak ostatnio zdanie i dopuścił możliwość uznania wyroku zasądzającego punitive damages przy spełnieniu określonych przesłanek — zob. orz. Corte di Cassazione, 5.07.2017, nr 16601/2017. W Polsce możliwość wykonania amerykańskiego orzeczenia zasądzającego punitive damages została zakwestionowana przez Sąd Najwyższy w post. z 11.10.2013, I CSK 697/12. 
różny. W niektórych europejskich systemach prawnych przyjmuje się, że odszkodowanie karne może być zaakceptowane o ile spełnia wymogi proporcjonalności (jest proporcjonalne do szkody) ${ }^{61}$. Może zatem zdarzyć się tak, że amerykański wyrok zasądzający punitive damages zostanie uznany w państwie członkowskim, w którym odszkodowania tego typu uważa się za możliwe do zaakceptowania (w całości lub w części), choć byłoby to nie do pomyślenia $\mathrm{w}$ innym państwie Unii. W takiej sytuacji dopuszczenie możliwości uznania orzeczenia zatwierdzającego wydanego przez sąd pierwszego z państw członkowskich w innym państwie Unii (co oznaczałoby rezygnację $\mathrm{z}$ kontroli pierwotnego wyroku wydanego w USA), prowadziłoby do potencjalnego obejścia zasad porządku publicznego w tym drugim. Dlatego możliwość taką należy odrzucić.

Rozważa się czasem, czy nie można przyjąć, że sąd w państwie pośrednim, który orzeka o uznaniu lub stwierdzeniu wykonalności wyroku z państwa trzeciego, ma także kompetencję do badania jego zgodności z porządkiem publicznym państwa docelowego. Innymi słowy, poddaje się w wątpliwość, czy wyłącznie sąd, o którego porządek publiczny chodzi, może badać zgodność uznania zagranicznego orzeczenia z własnym porządkiem publicznym, czy też sąd państwa pośredniego mógłby dokonywać kontroli zgodności z porządkiem publicznym państwa docelowego ${ }^{62}$. Wydaje się jednak, że kompetencja do kontrolowania zgodności wyroku zagranicznego sądu z podstawowymi zasadami porządku publicznego jest immanentnie związana z funkcją kontrolną wykonywaną w państwie, w którym dany wyrok ma być uznany lub wykonany (tj. w państwie, o którego porządek publiczny chodzi). Przemawiają za tym racje nie tyle

${ }^{61}$ Orz. Cour de Cassation (Francja) w sprawie Schlenzka v. Fountaine Pajot, Cass. Civ. 1.12.2010, "Journal du Droit International" 2011, nr 3, s. 615 (z glosą O. Boskovic); orz. Tribunal Supremo (Hiszpania) z 13.11.2001 r. w sprawie Miller Import Corp. v. Alabastres Alfredo, S.L., J.T.S., nr 1803 oraz ostatnio również Corte di Cassazione (Włochy), 5.07.2017, nr 16601/2017. W doktrynie na temat uznawania w Europie punitive damages zob. np. J. Zekoll: The Enforceability of American Money Judgments Abroad: A Landmark Decision by the German Federal Court of Justice. "Columbia Journal of Transnational Law" 1992, vol. 30, s. 641; P. Hay: The Recognition and Enforcement of American Money-Judgments in Germany. "American Journal of Comparative Law" 1992, vol. 40, s. 729 i nast.; F-X. Licari: Note au jugement Schlenzka v. Fountaine Pajot, Cour d'Appel Poitiers, 26.2.2009. "Journal du Droit International" 2010, n 4, s. 1230; C. Vanleen hove: A Normative Framework for the Enforcement of U.S. Punitive Damages in the European Union: Transforming the Traditional 'No Pasarán!' "Vermont Law Review" 2016, vol. 41, s. 348 i nast. W polskiej doktrynie por. w szczególności M. Syska: Wysokość zasqdzonego odszkodowania oraz tzw. punitive damages a klauzula porzqdku publicznego $w$ postępowaniu o stwierdzenie wykonalności orzeczenia zagranicznego. "Przegląd Sądowy" 2015, nr 1, s. 47 i nast.

${ }^{62}$ Wątpliwość taką wyraża P. Hay: Recognition of a Recognition Judgment Within..., s. 149. 
dogmatyczne co praktyczne. Po pierwsze, przyjęcie, że sąd państwa pośredniego bada zgodność uznania lub wykonania wyroku pochodzącego z państwa $\mathrm{X}$, nie tylko z własnym porządkiem publicznym (do czego jest uprawniony i jednocześnie zobowiązany), ale także z porządkiem publicznym państwa docelowego jest nieracjonalne i fikcyjne. Sąd państwa pośredniego nie jest bowiem zainteresowany w chronieniu porządku publicznego państwa docelowego. Wymaganie tego od sędziego państwa pośredniego wydaje się nierealistyczne. Po drugie, w ramach klauzuli porządku publicznego ocenia się czy uznanie lub wykonanie zagranicznego orzeczenia (jego indywidualne skutki), a nie samo orzeczenie jako takie, jest zgodne z porządkiem prawnym państwa uznania lub wykonania. Ocenianie przez sąd państwa pośredniego czy uznanie lub wykonanie wyroku w państwie docelowym będzie naruszało porządek publiczny tego drugiego byłoby niezwykle trudne, jeżeli nie niemożliwe. Po trzecie, na tym etapie może nie być jeszcze wiadome, gdzie docelowo wierzyciel będzie dochodził uznania lub wykonania korzystnego dla niego rozstrzygnięcia (tj. gdzie znajduje się państwo docelowe). Nie wiadomo zatem, jakiego państwa porządek publiczny należałoby brać pod uwagę. Jakiekolwiek spekulacje $\mathrm{w}$ tym względzie są nieuprawnione. Wszystko to przemawia za zarezerwowaniem kontroli w oparciu o klauzulę porządku publicznego dla sądu państwa, o którego porządek publiczny chodzi (tj. tego, w którym wierzyciel $\mathrm{w}$ danym momencie dochodzi uznania lub wykonania).

Nieco innym jest kwestia czy orzeczenie zatwierdzajace wydane w państwie pośrednim nie powinno wiązać sądu w państwie docelowym, w zakresie w jakim jego przedmiotem jest ocena pod katem zgodności pierwotnego wyroku z wymogami procesowego porządku publicznego (prawa do rzetelnego sądu i innych gwarancji procesowych) lub pod katem zgodności z zasadami europejskiego porządku publicznego. Można podnosić, że jeżeli w państwie pośrednim była okazja ocenić czy pierwotny wyrok został wydany w zgodzie z poszanowaniem dla podstawowych gwarancji procesowych to ocena ta wiąże sąd w państwie docelo$\mathrm{wym}^{63}$. Prawo do rzetelnego sadu i inne gwarancje procesowe to wszakże w dużej mierze zasady uniwersalne. Argument ten będzie szczególnie doniosły w kontekście unijnym, tj. gdy chodzi o związanie orzeczeniem zatwierdzajacym wydanym $\mathrm{w}$ innym państwie członkowskim $\mathrm{UE}^{64}$. W całej Unii obowiązuja bowiem podobne standardy prawa do rzetelnego sadu wyznaczone m.in. art. 47 Karty Praw Podstawowych ${ }^{65}$ i art.

${ }^{63}$ Tak przyjmuje się w USA i Kanadzie. Zob. P. Hay: Recognition of a Recognition Judgment under Brussels I?

${ }^{64}$ Zob. orzecznictwo sądów niemieckich cytowane przez ibidem.

${ }^{65}$ Karta Praw Podstawowych Unii Europejskiej. Dz.Urz. UE C 326 z 26.10.2012, s. 391. 
6 Europejskiej Konwencji Praw Człowieka ${ }^{66}$. Można twierdzić, że jeżeli takiej oceny dokonał sąd innego państwa członkowskiego to zasada wzajemnego zaufania nakazuje ocenę tę uszanować. Podobny argument dotyczy sytuacji, w której sąd innego państwa członkowskiego (jako sąd pośredni) miał okazję ocenić zgodność pierwotnego wyroku z zasadami europejskiego porządku publicznego (np. europejskim prawem konkurencji czy traktatowymi swobodami). Także wtedy chodzi bowiem o ochronę wspólnych wszystkim państwom członkowskim zasad i wartości.

Przeciwko takiemu związaniu oceną sądu państwa pośredniego można podnieść dwa kontrargumenty. Po pierwsze, jeżeli orzeczenie zatwierdzające państwa pośredniego miałoby wiązać sąd państwa docelowego, to musiałoby podlegać uznaniu w tym państwie. Skoro jednak wiązać ma jedynie ocena $\mathrm{w}$ przedmiocie procesowego i europejskiego porząku publicznego to należałoby przyjąć, bądź, że uznanie orzeczenia zatwierdzającego jest częściowe, bądź też, że uznane orzeczenie nie wiąże w całości. Z dogmatycznego punktu widzenia obydwa rozwiązania budzą wątpliwości ${ }^{67}$. Po drugie, pomimo normatywnego nakazu wzajemnego uznawania orzeczeń z innych państw członkowskich, nie wydaje się aby słusznym było całkowite zrzeczenie się kontroli pod kątem zgodności pierwotnego wyroku z podstawowymi zasadami procesowego i europejskiego porządku publicznego. Czy możemy mieć wszakże pewność, że sąd delibacyjny państwa pośredniego dokonał wystarczająco szczegółowej, rzetelnej i niezawisłej oceny tych okoliczności? Potrzeba zagwarantowania przestrzegania praw jednostek (chronionych podstawowymi gwarancjami procesowymi i zasadami prawa unijnego) wymaga zachowania instrumentu umożliwiającego uruchomienie wyjątkowej kontroli, nawet przeciwko orzeczeniu pochodzacemu z innego państwa członkowskiego. Pozostaje to $\mathrm{w}$ zgodzie $\mathrm{z}$ systemem uznawania i wykonywania orzeczeń ustanowionym w rozporządzeniu Bruksela I bis, w którym zachowano przecież klauzulę porządku publicznego jako przesłankę odmowy uznania i stwierdzenia wykonalności orzeczeń z innych państw członkowskich.

${ }^{66}$ Europejska konwencja o ochronie praw człowieka i podstawowych wolności z 4 listopada 1950 r. Dz.U. 1993, nr 61, poz. 284.

${ }^{67}$ Możliwe jest oczywiście częściowe uznanie zagranicznego orzeczenia w zakresie w jakim chodzi o różne roszczenia stwierdzone wyrokiem sądu państwa pochodzenia. Zob. post. SN z 11.10.2013 r., I CSK 697/12 (dopuszczalne jest częściowe stwierdzenie wykonalności zagranicznego orzeczenia w zakresie tylko jednego roszczenia, jeżeli jego przedmiot jest podzielny). Czym innym byłoby jednak uznanie zagranicznego orzeczenia w zakresie określonych motywów rozstrzygnięcia (ocena pod kątem procesowego i europejskiego porządku publicznego), przy jednoczesnym nieuznaniu orzeczenia pod katem innych motywów. 
Wydaje się jednocześnie, że całkowite ignorowanie orzeczeń zatwierdzających pochodzących z innego państwa członkowskiego byłoby niewłaściwe. Chodzi tu w szczególności o przypadki, w których w innym państwie członkowskim uznano już lub stwierdzono wykonalność wyro$\mathrm{ku}$ pochodzącego spoza Unii. Zasada wzajemnego zaufania domaga się uwzględnienia okoliczności, że wyrok taki już został zaaprobowany na terenie jednego z państw członkowskich UE. W literaturze zasugerowano $\mathrm{w}$ zwiąku z tym, że sąd państwa docelowego powinien wziąć pod uwagę orzeczenie zatwierdzające wydane przez sąd delibacyjny państwa pośredniego ${ }^{68}$. Watpliwości może oczywiście budzić na czym owo „branie pod uwage" miałoby polegać, skoro orzeczenie zatwierdzajace nie podlega uznaniu w państwie docelowym. Wydaje się, że chodzi tu przede wszystkim o uwzględnienie rozumowania sądu państwa pośredniego $\mathrm{w}$ podejmowaniu decyzji. Orzeczenie zatwierdzające wydane w pośrednim państwie uznania lub wykonania (szczególnie w innym państwie unijnym) może oddziaływać poprzez swój ciężar gatunkowy — własną „siłą przekonywania”69. W szczególności zaś należy wziąć pod uwagę dokonana przez ten sąd ocenę pod kątem zgodności pierwotnego wyroku z wymogami procesowego oraz europejskiego porządku publicznego. Rozstrzygnięcie sądu państwa pośredniego nie ma jednak mocy wiążącej dla sądów w państwie docelowym. Warto w tym miejscu zwrócić uwagę, że $\mathrm{w}$ Polsce zagraniczne orzeczenie stanowi dokument urzędowy w rozumieniu art. 244 k.p.c., a więc jest dowodem tego co zostało w nim urzędowo zaświadczone $^{70}$. Nie ogranicza to jednak swobody polskiego sądu w ocenie pierwotnego wyroku pod kątem jego zgodności z naszym porządkiem publicznym $^{71}$. Podkreślmy, że przedmiotem uznania lub stwierdzenia wykonalności jest tu pierwotny wyrok merytoryczny, a nie orzeczenie zatwierdzające.

${ }^{68}$ Tak P. Wautelet, in: Brussels I... (ed. 1). Eds. P. Mankowski, U. Magnus, s. 545

${ }^{69}$ Tak K. Kerameus: Enforcement..., s. 473.

${ }^{70}$ Zob. post. SN z 6.11.2009 r., I CSK 159/09. OSP 2010, nr 10, poz. 97.

${ }^{71}$ Por. orz. francuskiego Court de Cassation z 4.10.2005 r. Dalloz 2006, s. 2449, w którym przyjęto, że francuski sąd delibacyjny powinien wziąć pod uwagę zagraniczne orzeczenie jako „fakt prawny” (fait juridique) w ramach oceny prowadzonej w postępowaniu z wniosku o uznanie lub stwierdzenie wykonalności wyroku obcego sądu (chodziło o wyrok amerykańskiego sądu, którego wykonalność została wcześniej stwierdzona orzeczeniem sądu na Gibraltarze). 


\section{Podsumowanie}

Przedmiotem niniejszego opracowania było zagadnienie dopuszczalności uznania lub stwierdzenia wykonalności zagranicznych orzeczeń zatwierdzających, tj. rozstrzygnięć, których przedmiotem jest uznanie lub stwierdzenie wykonalności wyroku pochodzącego z jeszcze innego państwa. W moim przekonaniu, orzeczenia tego typu nie powinny być uznawane (i nie powinno się stwierdzać ich wykonalności), bez względu na to czy chodzi o orzeczenia zatwierdzajace pochodzace z państwa trzeciego (spoza UE), czy z państwa członkowskiego Unii. Orzeczenia zatwierdzające w ogóle nie mają zdatności uznaniowej (nie przysługuje im tzw. „równoległe uprawnienie”). Uznawać i wykonywać należy wyroki wydane $\mathrm{w}$ ich pierwotnym państwie pochodzenia, a nie odnoszące się do nich orzeczenia zatwierdzające wydane w państwie pośrednim.

Uznanie lub stwierdzenie wykonalności orzeczenia zatwierdzającego pozbawiałoby sąd w państwie docelowym instrumentu kontroli pierwotnego wyroku, w szczególności zaś jego zgodności z podstawowymi zasadami porządku prawnego tego państwa. O ile można liczyć, że sąd państwa pośredniego dokona oceny zgodności pierwotnego wyroku z uniwersalnymi gwarancjami rzetelnego procesu sądowego, tudzież z zasadami europejskiego porządku publicznego (jeśli jest to sąd państwa członkowskiego UE), to państwo docelowe musi zachować możliwość skontrolowania obcego wyroku pod katem zgodności z własnym porządkiem publicznym.

$\mathrm{Na}$ tle unijnego reżimu uznawania i wykonywania orzeczeń sądowych można w tym kontekście podnosić wątpliwość czy należy całkowicie ignorować orzeczenia zatwierdzające wydawane przez sądy innego państwa członkowskiego. Zintegrowany system jaki kreuja przepisy Unii Europejskiej (zwłaszcza rozporządzenie Bruksela I bis) opiera się wszakże na zaufaniu do rozstrzygnięć pochodzacych $\mathrm{z}$ innych państw członkowskich. W mojej ocenie, uwzględnianie orzeczeń zatwierdzajacych z innych państw członkowskich nie powinno się jednak odbywać w oparciu o ich uznanie czy stwierdzenie wykonalności, lecz jedynie poprzez ich branie pod uwagę $\mathrm{w}$ procesie rozstrzygania w przedmiocie uznania lub stwierdzenia wykonalności pierwotnego wyroku. Oznacza to uwzględnienie tych orzeczeń $\mathrm{w}$ toku rozumowania prowadzonego przez sąd delibacyjny w państwie docelowym jako czynnika przemawiającego za uznaniem lub stwierdzeniem wykonalności pierwotnego wyroku. Dotyczy to w szczególności rozstrzygnięć sądów państw członkowskich Unii $\mathrm{w}$ zakresie $\mathrm{w}$ jakim wypowiadają się na temat zgodności pierwotnego wyroku z uniwersalnymi gwarancjami rzetelnego procesu sądowego lub 
z zasadami europejskiego porządku publicznego. Sąd delibacyjny nie jest jednak związany takim orzeczeniem zatwierdzającym ani jego uzasadnieniem. 